\title{
LECTURERS' PERCEPTIONS ON PORTFOLIO AS AN ASSESSMENT TOOL IN ENGLISH LANGUAGE TESTING
}

\author{
Arifiana Tri Wulandari \\ arifianatri@gmail.com \\ Bambang Widi Pratolo \\ bambang.pratolo@pbi.uad.ac.id \\ Rika Junianti \\ rikajunianti13@gmail.com \\ Universitas Ahmad Dahlan Yogyakarta
}

\begin{abstract}
Assessment is an aspect of learning process which the students should have. Portfolio is a famous assessment, and it is a type of alternative assessment. The use of portfolio in English learning is expected to increase the students' achievement. The aims of this study are (1) to understandhow the teachers give introduction of portfolio assessment toward the students, (2) to understand the system of portfolio assessment, (3) to describe the disadvantages of portfolio, (4) to identify the impacts of portfolio for the students, and (5) to understand the reasons of using portfolio in the classroom. This study was qualitative research. The participants of this study were two English lecturers who used portfolio as the assessment tool in their classes. The instrument used in this research was interview. To analyze the data, the portfolio was transcribed and analyzed manually. The result of this study showed that portfolio is very useful and effective technique to assess the students, and it can help both the lecturers and the students in learning process to get good achievement.
\end{abstract}

Keywords: portfolio, assessment, English learning

\section{INTRODUCTION}

Assessment is part of learning process. It is used after the students learn some materials, and it is also used to measure the understanding of the students. The teachers used assessment to assess the students' achievement in learning. Gultom (2016) stated that assessment is a subset of evaluation, and has to be done by the teachers to assess and evaluate students' learning achievement. Because of that, assessment becomes an important part in teaching and learning process. Brown (2004) mentioned that there are two types of assessment which are popular and commonly used in educational system. They are traditional assessment and alternative assessment. Traditional assessment is also called as authentic assessment, and it is a test which is used to determine whether the students pass or fail in the learning process, while the alternative assessment is a test which is used to help the students transform their weaknesses into their strengths.

According to Brown (2004), assessment is an ongoing process that encompasses a much wider domain. On the other hand, Brown stated that the assessment done in learning process includes students' activities such as answering the question,andgiving comment or suggestion. Assessment must contribute feedback or washback for the students after it is given. Assessment also has to betransparent so that the students recognize their advance and error. Capraro et al. (2012) define assessment is called as a process for documenting. In classroom context, assessment is more complex, and it provides measurable terms which has specific knowledge, skills, attitudes and 
beliefs, and what specific purpose should be assessed.

There are some previous studies which are similar with this study. Kaur \& Samad (2013) conducted a study in a secondary school in Malaysia involving nine ESL teachers as their participants. They used qualitative research, and used semi-structured interview and observation to collect data. Demirel \& Duman (2014) carried out an experimental research in a state school of Ankara. They invited 31 students as the subjects of their study. While, Eskici (2015) conducted a similar study in a higher education. The study design was descriptive quantitative research, and involved 189 students of the third and fourth grade. She used questionnaire for data collection. Meanwhile, this study used a qualitative design. To collect the data, the researchers used a semi-structured interview addressed to two lecturers.

This study focuses on the alternative assessment.Alternative assessment's goal is to require the students' product based on their abilities. Alternative assessment has many types of approaches. The alternative assessment is successful in teaching. The famous approach of alternative assessment is portfolio. It gives positive impacts in learning process. Basically, portfolio is not new technique because it was a popular technique since mid 80's. Portfolio gives a description about the learning process because it consists of all activities which happened in the classroom. In other situations, portfolio is used to evaluate the students as learning achievement. Brown (2004, 256) defines some materials of portfolio. They are essay, composition in draft and final forms, reports, project outlines, poetry, creative prose, artwork, photos, newspaper, magazine clippings, audio, video recording, presentation, demonstration, journal, diaries, tests, written homework exercise, notes on lectures, self-assessment, and peer- assessment. Based on the materials, the lecturers can use several of them to use in assessment process. Besides, the students were able to complete the assessment, and understand how to make the portfolio.

In Kurikulum 2013, portfolio can be used as the assessment of competence performance. The portfolio result will be considered to writethe students' report. Portfolio is part of authentic assessments which can reach the students' attitudes, knowledge and skills. Afrianto (2017) stated that the latest Indonesian school's curriculum (Kurikulum 2013) emphasizes on the use authentic assessment, and portfolio is one type of authentic assessment. Portfolio is formed from a systematic collection of student's works which showed the students' progress in teaching and learning process. Because of that, portfolio can help students get better achievement in learning process. Educators can also use portfolio to take decision in making students' report.

Recently, many teachers and lecturers use portfolio assessment to assess the students. Portfolio is an assessment approach which is systematic and logic. It is usedto reveal and assess the students objectively, comprehensively, and accurately.In addition, it is also relevant with the students' documents. By using portfolio, it can help the teachers and lecturers to tract the students' progress in teaching and learning, especially English learning. Besides, the teachers or lecturers can improve their practices in English teaching by using portfolio. Based on the background, this research intends (1) to understand how the lecturers introduce portfolio assessment to their students, (2) to understand the portfolio assessment system which is used by the lecturers, (3) to describe the disadvantages of portfolio assessment, (4) to identify the impacts of the given portfolio for the students, and (5) to understand the lecturers' reasons for using portfolio in the classroom. 


\section{UNDERLYING THEORIES}

The following are the discussion of some theories related to this research.

\section{Language Learning}

Before the assessment process, there is learning process. This research focuseson English language learning whichhas four skills including listening, speaking, reading, and writing, andit can be described asunity in teaching. The students will learn those four skills for their abilities in mastering language. The goal of listening skill is to make the students able to understand what people say in English. The aim of speaking skill is to make the students able to speak English fluently. The goal of writing skill is to make the students able to think critically in the form of writtenlanguage. In addition, the aim of reading skill is to make the students able to understand the content of a text, and find the main topic of the text.

According to Tomlinson (2011), learning is a conscious process which is committed by some relevant information as understanding about a material. Tomlinson argued that language learning consists of subconscious development of generalizations about how the language is used, and of skills which apply these generalizations to make communication. Language learning can be explicit or implicit, and declarative or procedural. Briefly, language learning is a conscious process which asks the students toaware and not aware about what they learn.It consists of knowledge which is divided as language system and language application.

Language learning is considered as second language. It is because language learning is required onlyat school. The learners learn a language which is different with their mother tongue. For example in Indonesia, the mother tongue of the learners is Indonesian, but then they learn English at school as their foreign language.

\section{Alternative Assessment}

Many experts propose theories about alternative assessment. In this research, the researcher presents some theories of alternative assessment. According to Brown \& Hudson (in Brown 2004, 251), alternative assessment is one of the productive techniques in learning because it contains something new and different compared to other assessments. On the other hand, this type of assessment is used to change the common assessment in order to require responsible test construction.

North Carolina State Department of Public Instruction defines alternative assessment as a cover moment that concludes certain number of alternatives to measure tests. Whereas, the traditional paper and pencil tests can be effective to appraise listening skill, but it cannot be effective in speaking and writing skill. It means that alternative assessment can be effective when it contains some skills, and it is a set of tests. According to Norris, Brown, Hudson and Yoshioka (1998), alternative assessment offers information which contains the learners' weaknesses and strengths, and it includes all activities in the classroom. In using alternative assessment, the process is more detail because it is recorded by alternative assessment tool. In alternative assessment, there are several advantages and disadvantages. BYU (Center for Teaching and Learning) defines four advantages and two disadvantages of alternative assessment. The advantages are: alternative assessment provides a mean of assessing valued skills, it provides more realistic setting for student performance, focuses on student exhibition and the level of effort taken by students. Moreover, it can be simple and straightened with the established learning products.

In short, alternative assessment can assess all skills in learning especially in 
English learning. Alternative assessment contains students' performance and students' works, and it is suitable with the curriculum's goals. For the disadvantages, alternatives assessment process can be exhausting for the time, work, instrument, substance, facilities, and budget. In addition, the scoring process of alternative assessment is occasionally more subjective. In conclusion, touse alternative assessment needs more time, effort, equipment, materials, facilities, and subjects because alternative assessment is doneduring the learning process. The result will be received at the end of learning process known as a report.

Another aspect in alternative assessment is the problems of alternative assessment. The teachers or lecturers must paymore attention to make a good assessment. The problems are reliability, validity, objectivity, standardization of mechanism, and implementation. To make a good assessment, the content must be reliable, valid, objective, and suitable with the standardization, and the implementation must be easy for the students. Before the assessment is given to the students, the assessment must be through several steps in order to make the assessment suitable for the students.

\section{Portfolio}

Portfolio is a popular assessment. Based on Genesee \&Upshur (1996 in Brown 2004, 256), portfolio is a meaningful set of students' tasks which demonstratestheir efforts, progress, and achievements in a lesson or a learning. It means that when the teachers used portfolio, the students can explain their weaknesses, and it will show their strengths as the students' achievement at the end. According to Arter \& Spandel (1992), portfolio is a purposeful collection of students' work that reflects their assignment, and effort that shows progress or attainment in specific domain. The collection in this context is several tasks of students which contain their effort, and those become the students' achievement in the classroom.

Paulson \& Paulson (1991) assumed that portfolio demonstrates students' progress, achievement, and selfreflection in one or more areas. They argued portfolio is a technique to help the students to get their achievement in many areas of learning. To support the experts' statement, Gottlieb (in Brown 2004) designed six attributes of portfolio. They are collecting, reflecting, assessing, documenting, linking, and evaluating.

The explanation of six attributes is explained as collection, it means that the portfolio is an expression of students' life and identities. As reflection, it means that the successful portfolio contains exercisessuch as journal, and self-assessment checklists are necessary object. As assessment, it means a lot as they rate the quality and the development over time. As documentation, portfolio demonstrates students' achievement, and not just an unimportant addition of a test and other more traditional assessments. As link, portfolio connects learner, educator, parent, society, and peers. It is an obvious result, produced with admiration that recognizes students' uniqueness. As evaluation, portfolio is time-consuming, but satisfying process for raising accountability.

Thus, portfolio is a technique in assessment. Portfolio is a purposeful collection which contains students' weaknesses and strengths. Portfolio also has some attributes to support the statements that is very useful for the students.

\section{The advantages of portfolio}

In using portfolio, there are some advantages. Genesee \& Upshur (1996) stated some advantages as follow:

1. Portfolio provides:

a. a continuous, cumulative record of language development. 
b. a holistic teaching

c. concept progression of students

d. chances for collaborative assessment and goal-setting between students, educators, and other students

e. opportunities to use metalanguage to talk about language

2. Portfolio promotes:
a. student entanglement in assessment
b. obligation for self-assessment
c. interaction with educators, parents, and students about learning
d. students ownership of and duty for their own learning
e. stimulus about learning
f. students' aptitude to devise critically about school assignment
g. collaborative,dividing classrooms.

Another expert who stated the advantages of using portfolio is Brown (2004, 257). In his book, he explains some advantages of portfolio, they are:

1. Portfolio brings up primary motivation, responsibility, and occupancy.

2. Portfolio promotes student-teacher interaction with the teacher as facilitator.

3. Portfolio individualizes learning and celebrates the uniqueness of each student.

4. Portfolio provides tangible witness of a students' work.

5. Portfolio simplifies crucial thinking, self-assessment, and refinement processes.

6. Portfolio offers facilities for collaborative work with peers.

7. Portfolio authorizes assessment of multiple dimensions of language learning.

Several advantages above explain that using portfolio gives positive impacts for the students. The students can get many activities includedin portfolio assessment system. Portfolio provides some aspects which can support the language learning achievement for the students. The teacher can also assess the students' achievement easily.

\section{Steps and guidelines of successful portfolio}

In the development of portfolio, there are some steps and guidelines which can help the teachers to create a portfolio. According to Brown (2004), steps and guidelines of successful portfolio are as follow:

1. State objectives clearly. Brown explains that portfolio specifies stated objective as objective of expanding a portfolio, indicating how those aims are connected to combine with affirmation of your recent specified curricular purposes. A portfolio obtains top authenticity and washback. It means that portfolio must contain the purposes of learning, and it must integrate with thecurriculumat school. In using portfolio, the teachers must give washback to increase the students' achievement.

2. Give guidelines on what materials to include. Brown says thatthe material should include the types of work. Hamp-Lyons and Condon (in Brown 2004) suggested to put it between student and teacher, but over the materials. They said that it can be beneficial to offer obvious direction on how to receive initiation since many learners never compose a portfolio and maybe confused about what to do. So, in the portfolio, the materials and direction should be given clearly, it can help the students to understand about the activity inthe portfolio.

3. Communicate the assessment criteria to the students. Brown defines the very important aspects and the very complicated of portfolio applicationis that self-assessment and teacher-assessment must be given to the students to get the maximum achievement. In this context, the teachers must serve 
some questionnaire to know the working criteria in language learning process in order to make the students receive better materials.

4. Show time within the curriculum for portfolio development. Brown suggested the teachers to confirm the students' time collection sideways for portfolio work (including in class period), and the teachers' opportunities to have conference are not compromised. In the portfolio assessment, the teacher designs time in the language learning process. It contains the homework and activities in the class.

5. Establish periodic schedules for reviewing and conferencing. It will be done at the end of learning process, so the students can know everything about their achievement of the lesson. It can also help the students to remember the material and do the examination.

6. Provide positive washback for final assessment. Portfolio serves as numerical scores, it can compare the students' performances, courses, and districts. Portfolio contains written work. Wolcott (in Brown 2004) proposed a holistic scoring scale ranging from oneto sixwhich based on the qualities as an addition of out-of grade, error-free work, profound of content, creativity, comity, writing manner, and agreement with the learner.

Mokhtaria (2015) also stated some steps in portfolio, as follows:

1. Stating the philosophy: the educators deliver their ideological stance related to the goals, teaching practices, etc.

2. Evidence collection: the main source of learning documentations such as students' evaluations, assignments, exams, etc.

3. Planning and preparation: the educators plan the purpose of portfolio, and it should be ordered by the government about the portfolio structure.

4. Assessment and examination: demonstrate to achieve the goal, exhibit the effort, demonstrate in communicative skills, demonstrate collaboration skills.

5. Shaping and organizing: it consists of title, table of contents, headings and subheadings, references, learning and teaching approach, explanatory statements.

Before making portfolio, the teachers should know several steps and guidelines of portfolio. It can help the teachers to use the portfolio in the classroom, so that the portfolio can be suitable for the students. Portfolio also provides some works for the students which can help the teachers to know the students' achievement about the materials especially in language learning process.

\section{The challenges of portfolio}

Although portfolio has many advantages in learning process, there are some challenges which will be found by the educators. Based on (Afrianto 2017), one of challenges related to the issue of its low reliability and comparability. In writing assignment, the educators must pay attention about the single score or grade because it is subjective. Moreover, the instructors have standard assessment. They follow the national standard of education. Recently, the government always increases the education standard, as educators must develop their techniques in teaching to achieve the standard and students' attainment. Joshi, Gupta \& Singh (2015) also argued that the main challenge in portfolio is subjective and nonstandardized, they defined portfolio can't be used to assessment aims. Another challenge is the acceptance of institution and administration to apply portfolio. To solve this problems, it requires skillful professional educators 
in order to portfolio assessment can use well in the education field.

In this case, the government should train the educators to improve their competences and skills. This is important to do in order to prepare the educators in using portfolio. In training, the educators will be guided to infuse portfolio assessment into instructional programs. Its goal is relevant to use portfolio assessment which should be encouraged more massively and intensively in the learning and teaching process.

There are several studies which are relevant and referred in this study. The first relevant study is The Use of Portfolio as an Assessment Tool in the Malaysian L2 Classroom written by Kaur \& Samad (2012). They found that teachers who used portfolio in teaching can help the students improve their achievment. The use of portfolio as an assessment tool can also contribute to a better understanding of English language and give some implications for teaching and assessment.

The second is Self-Assessment and Portfolio Production of Iranian EFL Learners written by Sajedi (2014). In his research, he found that the use of portfolio gives positive impacts for the students to find out their weaknesses and strengths.

The third is The Use of Portfolio in English Language Teaching and Its Effects on Achievement and Attitudewritten byDemirel \& Duman (2015). They used open-ended question to find the effects of portfolio. They found that the students are interested in portfolio in English language teaching, and they had positive attitude as the effect of portfolio.

The fourth is Portfolio-Tool for (self) Evaluation of Students-Future Teachers written by Mogonea (2015). She revealed that portfolio gives the advantages and limitations for the possibilities of (self) evaluation and optimization.
The last is University Students' Opinions on Application of Portfolio in Higher Education written by Eskici (2015). The researcher assumed that the use of portfolio is positive based on the students' opinion.

This study, as current research, is inspired by the previous studies. The researchers are interested in conducting a similar research in English learning based on the lecturers' perception, and it focused on writing skill. The researchers want to know the use of portfolio in English language learningof higher education especially in lecturers' perspectives.

\section{RESEARCH METHOD}

The type of this research is qualitative research. The research was conducted in a week, starting from November $5^{\text {th }}, 2018$ to November $10^{\text {th }}$, 2018. The subjects of this research were two lecturers from different universities. The purpose of this research wasto understand the lecturers' perception about the use of portfolio in English learning as an assessment tool. To collect data, the researcher used interview. The interview included some questions about portfolio which was used by the lecturers. To ensure the trustworthiness of the data, the researchers conducted member checking. The two lecturers who became the subjects of this study double checked the interview transcripts to make sure what was written was truly what they said in the interview.

\section{Discussions \\ Using Portfolio in Language Class}

Two lecturers explained why they use portfolio in language class. They have different reasons. The first lecturer explained that she used portfolio since the last semester. She used it because of university policy, and portfolio was designed to submit all materials which have ever been learnt by the students. The second lecturer explained that she often used portfolio, 
and it was based on her initiative. Portfolio helped her to make objective and meaningful assessment easily.

\section{Reasons in Using Portfolio}

There are some reasons to use portfolio. Basically, the lecturers used it to help them assessing the students easily. Besides, portfolio also includes the learning process since the beginning until the end of the process. At the same time, the students'activities have been recorded by the portfolio, and the lecturers can use it as guidelines to give final score. By using portfolio, the lecturers believed that the students can know their process step by step. This study found out why the lecturers use portfolio as explained briefly in the interview. Based on the interview, first lecturer said portfolio assessment is university policy, it will collect all of materials and assignments which are submitted by the students. Second lecturer gave different reason, she used portfolio because of her initiative. It can help the lecturer to provide objective and meaningful assessment easily.

\section{Learning Process by Using Portfolio}

In this subsection, the researcher describes few processes in English learning. At the beginning, the lecturers deliver the learning purpose. They assist some important ways during the learning process. It is intended to achieve the learning goals. In this study, the researcher found that the two lecturers use portfolio assessment for writing skill. The activity is the students write a journal or something which has been learnt. Each meeting, the lecturers ask the students to write as a learning process. After they write, their work must be collected in a map. It will be assessed at the end of the learning. Indirectly, all of the assignments must be completed because the assignments indicate that the learners attend the class.

\section{Introducing the Portfolio Assessment}

Before the lecturers deliver their material, they must explain the assessment process first. It is necessary because the students can prepare themselves to get the language learning purpose. It can also help them to improve their achievement. Another aim is that the lecturers want the students get the development of English language learning. It is because portfolio will record the students' activity. They can see their progress in every meeting. In interview section, the first lecturer stated that the students must use a map to submit the assignments. Every task which is given in learning process should be in the map. Besides, another lecturer affirmed that the course is process base. Then each step will be continued, the students are expected to follow that steps because it will be assessed.

\section{The Assessment System of Portfolio}

Apart from this, the lecturers explain how they assess the students' process. Basically, they have similar system which is the same with the goal of the assessment. The technique is based on students' learning process. First lecturer assesses the students by checking their assignment on the map. The students will get a task in each meeting. If one of the assignments lost, it means that the students didn't submit their work. Then second lecturer assesses the students based on their process. It means that the lecturer will assess by portfolio which includes the students' process.

\section{The Advantages of Portfolio}

Every assessment technique has advantages in learning process. It is also for portfolio assessment. The lecturers argued that portfolio has good advantages for the students. It can give better achievement, and it has good guideline for the next lesson especially in English language lesson. Using portfolio, the students can know their 
mistake.They can minimize their error in next assignment and guide them in doing a task in order to they will not do the same guilt. Another advantage is the students can know that they do a process.It will be shown in portfolio how the beginning and end performance which are done by the students.

\section{The Disadvantages of Portfolio}

Besides the advantages, portfolio assessment also has disadvantages. It is because the useof portfolio needs more times. Portfolio assessment is done during the teaching and learning process. The lecturers explain different disadvantages based on their perception and based on their experience in English teaching. In their experiences, using portfolio gives some weaknesses in language learning. The lecturers said that using portfolio takes time because they should check students' work one by one. They should be consistent in assessing, observing, and directing, and they should check it in detail towards the students mistake.

\section{The Impacts of Portfolio to the Students}

In using a technique during teaching learning process, the lecturers hoped that it can give benefits for the learners for their future or for other lessons. By using portfolio, the learners can understand more about the material which can guide them to accept learning goals. According to the lecturers' perception, there are many good impacts which are caused by portfolio such as stimulating development, reducing errors, and helping to memorize the material. It means that the students will get more helpto understand a material if the lecturers used portfolio in English assessment. It can assist the lecturers to consider the final score.

In the end of learning process, the students can receive some effects of portfolio, and it can affect them in other subjects. They will do the assignment well. The students also get a development based on their guilt, and the students will get betterment in writing. Besides, the students can understand what they have learned. Not just memorizing or limited knowing.

\section{ANALYSIS}

In this section, the researcher present the result of analysis in order to answer the research questions. This study found some important results. A good assessment occurs when students can receive the purpose of the learning. In fact, many students cannot understand the purpose of the learning, it is because the assessment did not include the question about it. In order to change this concept, lecturers should use and create the assessment system to anticipate the advance students in English class. Here, portfolio becomes the solution to solve the problems.

Teaching English using portfolio is a good assessment technique. The students submit all of their works in a map. By using this technique, students can have a significant progress. Both of lecturers confirmed all of their students get good achievement in the end of learning process. It can be seen on their works which always increase in every meeting. The students also get good scores and improve their skills. It is because portfolio can led to self monitoring, and make students become more confident in learning English. The result of this study supported the use of portfolio in English teaching and learning process. The samples were two lecturers from different universities. The result revealed that portfolio assessment was effective in English language testing.

Based on the interview result, the researcher found that the lecturers use portfolio as learning assessment. Its purpose is to help them in giving score at the final result. Although the lecturers did not mention the assessment system clearly, they explain what the students must do during the 
teaching and learning process. In fact, some students do not aware about the process.Based on the lecturers, the use of portfolio is very effective, and it gives good impacts for the learners in teaching and learning English process. For example, the learners can know their mistakes when they did an assessment. In the portfolio, the lecturers also write or give feedback in order to make the students more motivated to improve their skills.

Using portfolio, the students can know their weaknesses and strengths because portfolio records their progress. Portfolio also includes some opportunities for students. It is in line with the statement of Genesee and Upshur (1996), they explained that portfolio demonstrates the students' efforts, progress and achievement. Besides, the lecturers also have some steps in using portfolio successfully. It needs to be done in order to make the students follow the instructions correctly. The steps are in line with Browns' guidelines (2004). The portfolio must include clear purpose, contain assignment types, cooperate between learners and teachers, contain time setting, include evaluation section, and give washback.

Other researchers who are supported this study are Yurdabakan and Erdogan (2009) who argued that portfolio is the best approach which can increase the students' ability and can motivate them. Prastikawati, Sophia B \&Sodiq (2016) defined that writing skill through portfolio, and concluded that portfolio can achieve good result for the students. Javanmard and Farahani (2012) argued that portfolio gives significance positive influence on students' language.

In addition, this study found out the use of portfolio as an assessment tool which includes writing skill. Portfolio gives many influences on writing skill. The lecturers gave comment and feedback in students' work so that they will not do the same mistakes in next works. It means that portfolio will be successful in writing skill, and the students can know their progress for each assignment. Many other researchers support this study, and they report the benefits of portfolio assessment which is very useful and helpful.

\section{CONCLUSION}

Portfolio is a technique which can be used to assess the students in learning English. Portfolio can save all of students' progress in every meeting. Portfolio can also create the learning to be more effective and meaningful. Using portfolio can help the lecturers to assess students' step by step because they will do and submit the assignment on it. For students, portfolio can help them to minimize their mistake in next task. The students can also know their process because portfolio collects their assignments. Before using portfolio, the lecturers need to introduce portfolio, and how the portfolio assessment system. It needs to do in order to students did not confuse with the portfolio. In brief, this study recommended that portfolio is the best assessment tool in submitting all students' works, motivates the students and increase students' achievement in English learning. Portfolio is also very recommended for assessing students' work in writing skill. Portfolio assessment has beneficial approach to help the students in achieving their goals.

\section{REFERENCES}

Afrianto. 2017. "Challenges of Using Portfolio Assessment as an Alternative Assessment Method for Teaching English in Indonesia Schools". International Journal of Educational Best Practices, 1 (2)

Arter, JA \& V. Spandel. 1992. "Using Portfolios of Students Work in Instruction and Assessment". Educational Measurement: Issues and Practice, 11 (1): 36-44 
Brown, H. Douglas. 2004. Language Assessment: Principles and Classroom Practice. New York: Pearson Education

Capraro, RM, MF Roe, MM Caskey, D. Strahan, P. Bishop, C. Weiss \& KW Swanson. 2012. "Research Summary: Assessment". Association for Middle Level Education, 1-6

Chung, Sun J. 2012. Portfolio Assessment in ESL Academic Writing ExaminingThe Effects of Reflection in The Writing Process (Thesis) Urbana: University of Illinois

Demirel, Melek \& Hatice Duman. 2015. "The Use of Portfolio in English Language Teaching and Its Effects on Achievement and Attitude". Procedia Social and Behavioral Sciences, 191: 2634-2640

Efendi, Zuhri. 2017. "Improving Students' Ability in Writing English Teaching by Using Portfolio Assessment (An Experimental Study at SMKN 1 Blangpidie)". Getsempena English Education Journal, 4 (2)

Eskici, Menekse. 2015. "University Students' Opinions on Application of Portfolio in Higher Education". Procedia Social and Behavioral Sciences, 174: 2946-2955

Genesee, Fred \& Upshur, John A. 1996. Classroom-based Evaluation in Second Language Education. Cambridge: Cambridge University Press.

Gultom, E. 2016. "Assessment And Evaluation In EFL Teaching And Learning". Proceedings of ISELT FBS Universitas Negeri Padang, 4 (1): 190198

Huba, Mary E. \& Jann E Freed. 2000. Learner-Centered Assessment on College Campuses: Shifting the Focus from Teaching to Learning. Needham Heights: Allyn \& Bacon Inc.

Hung, Li-Ching. 2016. "Alternative Assessment: Can Portfolio Assessment Have Positive Impacts on EFLab Original Students' Learning Outcome?". International Journal of Management and Applied Science, 2 (9)

Javanmard, Yarmorad\& Hossein Farahani. 2012. "Investigating Using Portfolio Assessment and Learning English Language in Qom Schools". Global
Journal of Human Social Science: Linguistic \& Education, 12 (12)

Joshi, Mohit Kumar, Piyush Gupta \& Tejinder Singh. 2015. "Portfolio-Based Learning and Assessment." Indian Pediatrics, 52 (3): 231-35

Kalra, R, C. Sundrarajun \& H. Komintarachat. 2017. "Using Portfolio as an Alternative Assessment Tool to Enhance Thai EFL Students' Writing Skill". Arab World English Journal, 8 (4)

Kaur, Charanjit \& A. Abdul Samad. 2013. The Use of Portfolio as an Assessment Tool in the Malaysian L2 Classroom. International Journal of English Language Education, 1 (1)

Kuter, Sitkiye. 2009. Examination of the Merits and Pitfalls of the Internship Portfolio. Procedia Social and Behavioral Sciences, 1: 84-90

Mokhtaria, Lahmer. 2015. "The Use of Portfolio as an Assessment Tool." International Journal of Scientific \& Technology Research, 4 (07): 170-72

Mogonea, Florentina. 2015. "Portfolio-Tool for (Self) Evaluation of Students-Future Teacher". Procedia Social and Behavioral Sciences, 180: 860-864

Norris, JM, JD. Brown, T. Hudson \& J. Yoshioka, 1998. Designing Second Language Performance Assessment. Honolulu: University of Hawaii Press

North Carolina Department of Public Instruction - Second Language Instructional Service. 1999. Assessment, Articulation, and Accountability 1999: A Foreign Language Project. Public Schools of NC - Department of Public Instruction

Obeiah, Salameh F \& Ruba F Bataineh. 2016. "The Effect of Portfolio-Based Assessment on Jordanian EFL Learners' Writing Performance". Bellatera Journal of Teaching \& Learning Language \& Literature, 9 (1): 32-46

Paulson, FL, PR Paulson \& CA Meyer. 1991. "What Makes a Portfolio". Educational Leadership. 48(5): 60-63

Phung, Huy V. 2016. "Portfolio Assessment in Second/Foreign Language Pedagogy". Hawaii Pacific University TESOL Working Paper Series, 14: 90-107 
Prastikawati, EF, BC. Sophia \& J. Sodiq, 2016. "Portfolio Assessment Impacts on Writing Ability of English Foreign Language (EFL) Learners". IOSR Journal of Research \& Method in Education. 6(6): 11-18

Sajedi, Roghayeh. 2014. "Self-assessment and Portfolio Production of Iranian EFL Learners". Procedia Social and Behavioral Sciences, 98: 1641-1649

Suryoputro, Gunawan\& Rizal Akip. 2016. "Exploring EFL Students' Perception of Washback of Portfolios in Reading Assessment". International Journal of Language and Linguistics, 3 (2)

Tomlinson, Brian. 2011. Material Development in Language Teaching. Cambridge: Cambridge University Press
Ustunel, Eda \& Ertan Deren. 2010. "The Effects of e-Portfolio Based Assessment on Students' Perceptions of Educational Environment". Procedia Social and Behavioral Sciences, 2: 1477-1481

Yastibas, Ahmet E. \& Gulsah C Yastibas. 2015. The Use of e-Portfolio-based Assessment to Develop Students' Selfregulated Learning in English Language Teaching". Procedia Social and Behavioral Sciences, 176: 3-13

Yurdabakan, Irfan \& Tolga Erdogan. 2009. "The Effect of Portfolio Assessment on Reading, Listening, and Writing Skills of Secondary School Prep. Class Students". The Journal of International Social Research, 2 (9) 